\title{
COMMENTS
}

\section{DISSOLUTION AND MODIFICATION OF FEDERAL DECREES ON GROUNDS OF CHANGE OF ATTITUDE}

\section{I}

The power of federal courts to modify or dissolve injunctions and decrees enforcing cease and desist orders of administrative agencies has a significant impact upon the enforcement of regulatory statutes. Insofar as such injunctions and decrees embody findings concerning the status of the litigants at the time of issuance, they have the same finality as other judgments; but as continuing regulations of conduct, it is well settled that they are subject to modification or dissolution to prevent injustice when there is a change in the law or factual conditions on which they are based. ${ }^{2}$ However, it has never been clearly established whether, if the enjoined conduct remains indisputably illegal, an increase in the willingness of the enjoined party to comply with the law justifies modification or dissolution.

In the leading case of United States v. Swift $\& \mathrm{Co}{ }^{3}$ the Supreme Court stated that a final, permanent injunction may be modified or dissolved only upon a clear showing by the enjoined party of serious hardship "evoked by new and unforeseen conditions." "In the Swift opinion Mr. Justice Cardozo

${ }^{1}$ Some of the federal acts which rely for their enforcement entirely or in part on injunctions or court decrees enforcing the cease and desist orders of governmental agencies are: Clayton Act, 38 Stat. 731 (1914), as amended, 15 U.S.C.A. \$21 (1951); Fair Labor Standards Act, 52 Stat. 1069 (1938), as amended, 15 U.S.C.A. $\$ 45$ (1951); Interstate Commerce Act, 62 Stat. 931 (1948), as amended, 15 U.S.C.A. \$21 (1951); Labor-Management Relations Act, 1947, 61 Stat. $14 \$$ (1947), as amended, 29 U.S.C.A. \$160(e)(f) (1956); Securities Exchange Act, 1934, 48 Stat. 900 (1934), as amended, 15 U.S.C.A. 78u(e) (1951); Sherman Anti-Trust Act, 26 Stat. 209, as amended, 15 U.S.C.A. $\$ 4$ (1951).

2 E.g., United States v. Swift \& Co., 286 U.S. 106 (1932); Western Union Telegraph Co. v. International Brotherhood of Electrical Workers, 133 F.2d 955 (C.A.7th, 1943); Stewart Die Casting Corp. v. NLRB, 129 F.2d 481 (C.A.7th, 1942); Jones v. Mississippi Valley Barge Line Co., 107 F.Supp. 157 (W.D. Pa., 1952). See, Power of the Court to Modify a Final Permanent Injunction, 46 Mich. L. Rev. 241 (1947).

3286 U.S. 106 (1932). Swift \& Co. requested modification of a consent decree forbidding it from going into the business of retailing many types of groceries. The request was based on the contention that market conditions had changed since the issuance of the decree; the industry had become, it was claimed, more competitive and the retail grocers had improved their position in relation to wholesalers. The Supreme Court stated that it had power to modify the decree but held that since Swift \& Co. had not proved that the enjoined conduct would no longer adversely affect its competitors, the requirement-that the danger which the decree was designed to prevent must be eliminated-had not been met; therefore dissolution could not be granted.

286 U.S. 106, 119 (1932). 
did not speak directly to the question whether this test should be applied when only the defendant's willingness to comply had changed. No cases have been found in which the Supreme Court has considered this question. In three recent decisions, each involving a broad decree prohibiting violation of the Fair Labor Standards Act, the Courts of Appeals have split on the issue.

In Tobin v. Alma Mills, the Court of Appeals for the Fourth Circuit held that the Swift decision did not prevent the dissolution of an injunction when the enjoined party had demonstrated his willingness to abide, without the threat of contempt penalties, by the terms of the decree. The Court of Appeals affirmed the action of the District Judge who, relying on Federal Rule 60(b) (5) and (6), had dissolved the injunction on the ground that it was no longer equitable that it should have prospective application. The Eighth Circuit, in Tobin v. Little Rock Packing Co., ${ }^{6}$ followed the lead of the Fourth Circuit. In Walling v. Harnischfeger Corp., ${ }^{7}$ however, the District Court for the Eastern District of Wisconsin held that it was prevented by the Swift case from giving relief in a fact situation similar to that presented in the Alma Mills and Little Rock Packing Co. cases. This decision was affirmed by the Court of Appeals for the Seventh Circuit. ${ }^{8}$

5192 F.2d 133 (C.A.4th, 1951), cert. denied 343 U.S. 933 (1952). Alma Mills petitioned for dissolution on the ground that it had complied with the law for more than ten years. The decree, it was claimed, was hampering a sale of stock. When the FLSA administrator was notified of the motion for dissolution, he investigated and found only technical violations. The court, dissolving the decree, held that compliance with the statute for the ten year period was a change of condition which made it unfair for the judgment to be continued. The Swift case was distinguished on the ground that the Supreme Court had not found a change of condition in that case.

Several years earlier a district court in the same circuit held that operation under a decree for six years without being cited for contempt was sufficient to establish the willingness of the enjoined party to comply with the FISA. McComb v. Lexington Lumber Co., 15 CCH Lab. Cas. 164885 (E.D.S.C., 1948). The court held that the change in the willingness of the party was a ground for dissolution under Rule 60 (b)(5) of the Federal Rules of Civil Procedure. No reference was made to the Swift rule.

' 202 F.2d 234 (C.A.8th, 1953), cert. denied 346 U.S. 832 (1953). The Little Rock Packing Co. was sued for contempt for allegedly committing certain technical violations of the FLSA." The company denied that it was guilty of contempt and requested dissolution of the injunction. The court acquitted the company of criminal contempt but found it guilty of technical contempt and assessed $\$ 400$ as costs of the suit. The court dissolved the injunction on the ground that the company had operated under the decree for nearly ten years and had committed only technical violations during that period.

7142 F.Supp. 202 (E.D. Wis., 1956). The court cited the Swift case and argued that, since it could not be said that the issuing judge had anticipated that the defendant would not comply with the decree, a change of attitude would not be "unforeseen." This argument has the effect of changing the standard in the Swift case from "unforeseen" to "unforeseeable." The latter term apparently includes only those changes which were or would have been thought improbable had they been considered.

8242 F.2d 712 (C.A.7th, 1957). There is some doubt about the meaning of the decision of the Court of Appeals. The District Court had specifically rejected the Alma Mills and Little Rock Packing Co. cases. However, the Court of Appeals distinguished those cases on 
II

Only if it (1) is unforeseen and (2) causes a serious hardship for the enjoined party does a change in the willingness of an enjoined party come within the Swift doctrine. It is not clear what the Court meant in the Swift case by the term "unforeseen."

The term "unforeseen" clearly includes those changes which the issuing judge considered and found improbable. Changes not considered at all would also seem to fall within the meaning of "unforeseen" regardless of whether the change, if it had been considered, would have been thought improbable. No opinion has been found in which the wisdom of limiting the meaning of "unforeseen" in the Swift rule was discussed. It would seem that because the common usage of the word connotes any unconsidered change and since, moreover, there is no indication in the Swift case that the Court meant to give the word a special meaning, either a change which was considered and found improbable or an unconsidered change should meet the requirement of being "unforeseen." It seems unwise to exclude, as did the lower court in the Harnischfeger case, ${ }^{3}$ changes which were not considered but, if they had been, would have been found probable. Such a limitation of the term "unforeseen" would prevent the parties from litigating the effect which a particular change should have. ${ }^{10}$ It would also be unwise to limit "unforeseen" by requiring that the issuing judge must have considered the likelihood of a given change. Such a restriction would make the possibility of modification or dissolution vary with the diligence and imagination of the issuing judge and the litigants.

The second requirement of the Swift rule is that the "hardship" be "evoked by" the change of condition. If "hardship" means simply "handicap," a change of attitude cannot satisfy the "evoked by" requirement. It cannot be said that one who is willing to comply with a decree bears more of a burden than one who is unwilling to comply. If, however, the term "hardship" implies an element of injustice-an unfair handicap-then the "evoked by" requirement

the ground that they involved the granting of dissolution by district courts while the Harnischfeger case involved a denial of dissolution by the District Court. It might be argued that the Court of Appeals was resting its decision on the ground that the district judge had considerable discretion in dissolving decrees. However, it seems unlikely that such a position would be taken in a case in which the District Court had stated that "in the event this court is erroneous in its view of the position of [the Court of Appeals for the Seventh Circuit] defendant has a ready and inexpensive remedy by way of appeal." 142 F.Supp. 202, 205 (E.D. Wis., 1956).

${ }^{9}$ See note 7 supra.

${ }^{10} \mathrm{It}$ would be impossible to anticipate all possible changes of condition. It would, moreover, be excessively time consuming if the attorneys were to litigate the effect which the many conceivable changes should have. Assume that the effect of $X$, a change of condition which would have been considered probable, is not litigated at the issuance proceeding and later occurs. Dissolution will not be granted if it is sought on the ground that it was probable that $\mathrm{X}$ would occur. Thus at no time has the enjoined party had the opportunity to litigate the effect which $\mathrm{X}$ should have. 
may be met. While it may be just to impose special disabilities on a party whose conduct demonstrates opposition to the law, it seems unfair to impose the same disabilities on a party who will comply with the law without the threat of penalties. Consequently, if a liberal interpretation of "unforeseen" and "hardship" is adopted, decrees may be modified or dissolved on grounds of change in willingness to comply; if a restrictive interpretation of those terms is used, the enjoined party cannot obtain relief.

If a restrictive interpretation of the Swift rule is followed, anomalous results will be produced. An injunction is issued only after two elements are established: (1) that certain conduct is illegal or will produce an illegal result and (2) that the defendant, if not enjoined, will probably engage in such conduct." It is well established that a change in the first element is sufficient to warrant dissolution or modification. There seems to be no reason why a change in the second element should not have the same effect.

The significance of attitude, and therefore the degree of anomaly, depends on several factors. Where the scope of a decree is narrow and the terms specific, as for example when the FTC secures a decree forbidding a manufacturer from adding a certain chemical to his product, the defendant's attitude may be unimportant. Where a broad range of conduct is prohibited by a decree and the prohibitions represent clarifications or previously uncertain points of law, the primary issue litigated is likely to be that of the legality of the conduct rather than the defendant's attitude. In such a case, though, as will be discussed later, ${ }^{12}$ an increase in the defendant's willingness to comply may well be significant for purposes of granting dissolution or modification of the decree. Attitude may also be important with respect to decrees which the issuing court phrased in broad terms because the defendant demonstrated hostility to all or major portions of a statute. Decrees enjoining conduct of a type different from the illegal acts performed before the issuance proceeding is permissible only where the defendant has shown that he is hostile to the statute in general. Such decrees are frequently phrased in terms of broad statutory language indicating that the legality of the conduct prohibited by that part of the decree was not in question since the statute is determinative on that point. ${ }^{13}$ Where, as in

\footnotetext{
"I Even where past offenses have been committed, a court need not issue an injunction if it believes that future compliance can be secured without the threat of contempt penalties. See cases cited in The Statutory Injunction as an Enforcement Weapon of Federal Agencies, 57 Yale I. J. 1023 (1948). The decree may cover violations of a sort not yet committed by a party. This is done when the defendant's attitude shows that the decree is needed to prevent a broad range of activities. NLRB v. United Mine Workers, 202 F.2d 177 (C.A.3d, 1953). See note 13 infra.

12 See discussion at 665 infra.

${ }^{13}$ Such decrees were common under the National Labor Relations Act during the late 1930's. It has been held that the NLRB has the same powers as a court of equity in determining the scope of its decrees and that the test to be applied by the courts is whether the Board could reasonably conclude from the evidence that the defendant's hostility to the statute was
} 
these cases, attitude has played a major part in determining the issuance or scope of a decree, it would seem justifiable to grant dissolution if the enjoined party demonstrates a marked increase in his willingness to comply with the terms of the decree.

The anomaly which results from refusing to grant dissolution in such cases is made more striking by the consideration that, while the illegality of the conduct is usually hotly litigated at the proceedings for the issuance of the decree, the question of attitude often may not be brought sharply into focus. The finding of the court about the defendant's attitude at the time of the decree may be largely pro forma. There is unlikely to be a reasoned decision about how long the defendant will probably violate the law. These considerations buttress the conclusion that it is unjust to perpetuate a decree when the enjoined party can demonstrate a substantial increase in his willingness to abide by the law. Thus, opinions like that in the Harnischfeger case appear unsound.

Such opinions cannot be supported, as the District Court in Harnischfeger tried to do, on the ground that because the issuing judge made the decree "permanent" and that he would probably have considered a change of attitude probable, ${ }_{2}^{14}$ he must have meant the decree to continue despite such a change. To refuse dissolution on such grounds seems unreasonable unless the possibility of the change in question was actually litigated at the issuance proceeding. Such a refusal, moreover, cannot be reconciled with the long-established principle that dissolution may be secured when there is a change in the law or factual conditions upon which a decree is based; for it is probable that the issuing judge would not have thought that the law and facts on which the decree is based would remain forever unchanged.

Although it thus appears reasonable to grant modification or dissolution when an enjoined party proves his willingness to comply with the law, a court cannot, as has been shown, take such action so long as the Swift rule is narrowly construed and held applicable. Therefore, unless the enjoined party can obtain the relief he needs through procedures for determining whether certain contemplated action violates the terms of the decree under which he is operating, it

such that a decree of the scope used was necessary to prevent him from violating the statute. May Stores Co. v. NLRB, 326 U.S. 376 (1945). Under this rule, injunctions which have the effect of prohibiting the enjoined party from interfering in any way with the rights of employees to bargain collectively have been sustained on findings that the employer had offered to make wage increases once the employees had disaffiliated themselves from the union and polled the employees to see if they wished to remain in the union. NLRB v. Charles R. Krimm Lumber Co., 203 F.2d 194 (C.A.2d, 1953). Accord: NLRB v. May Stores Co., 154 F.2d 533 (C.A.8th, 1946); NLRB v. Reeves Rubber Co., 153 F.2d 340 (C.A.9th, 1946). But cf. NLRB v. Matthews \& Co., 156 F.2d 706 (C.A.3d, 1946); NLRB v. Federal Engineering Co., 153 F.2d 233 (C.A.6th, 1946).

${ }^{14}$ The court spoke in terms of compliance rather than of change in attitude. However, it is diffcult to see any significance in the amount of time during which the defendant has complied except as evidence of a change in attitude. 
would seem sensible to give a liberal interpretation to the Swift rule or else hold it inapplicable.

The enjoined party can obtain some relief through procedures for determining whether the acts he contemplates will subject him to contempt penalties. He may be able to maintain a suit for a declaratory judgment. ${ }^{15}$ The near equivalent of a declaratory judgment can be obtained from administrative agencies authorized to issue declaratory orders subject to judicial review. ${ }^{16}$ If this procedure is constitutional ${ }^{17}$ and made easily available, ${ }^{18}$ defendants operating under decrees obtained by such agencies can mitigate the hardships. However, obtaining relief by such procedures is often costly and slow. Moreover, only immediate problems are solved; the enjoined party must still operate under the decree. It would, therefore, seem that dissolution or modification are the most practicable methods of providing relief. To grant dissolution or modification, the Swift rule must, as pointed out above, be construed liberally or held inapplicable.

Neither course is unjustifiable. Neither the facts nor the opinion in the Swift case in any way indicate that the Court considered the question what effect a change of attitude should have on a decree. The case could therefore be distinguished. Perhaps the most feasible solution is to liberally construe the Swift rule. The liberal interpretations suggested above for the terms "unforeseen" and "hardship" comport with the normal usage of those words. The case for the liberal interpretations is strengthened by the fact that Rule 60(b) (5) and (6) of the Federal Rules of Civil Procedure were promulgated since the Swift decision. That rule was said to embody existing law. ${ }^{19}$ Its emphasis is on fairness and justice for the enjoined party. It provides that a fair balancing of the competing interests should govern the dissolution or modification of injunctions. ${ }^{20}$ The interests to be balanced are the hardships to the enjoined

${ }^{15}$ Ladner v. Siegel, $294 \mathrm{~Pa} .368,144$ Atl. 275 (1928); Borchard, Declaratory Judgments 181 (1st ed., 1934). See also Fraser, A Survey of Declaratory Judgment Actions in the United States, 39 Iowa L. Rev. 639 (1954); Pugh, The Federal Declaratory Remedy: Justiciability, Jurisdiction and Related Problems, 6 Vand. I. Rev. 79 (1952); Injunctions-Possibility of Clarification by Declaratory Judgment, 6 U. of Chi. L. Rev. 310 (1939).

${ }^{16}$ Administrative Procedure Act, 60 Stat. 239 (1946), 5 U.S.C.A. \$1004 (Supp., 1950).

${ }^{17}$ A provision for judicial review of the declaratory orders of agencies would be unconstitutional unless it can be said that a case or controversy is created by the orders. The case or controversy requirement may be satisfied. In Frozen Food Express v. United States, 351 U.S. 40 (1956), the Supreme Court held that the district court had jurisdiction to hear an appeal from a declaratory order of the ICC specifying which commodities were within the agricultural exemption provision in the Interstate Commerce Act.

18 For a discussion of advisory and declaratory opinions and some of the situations in which an agency will give such opinions, see Davis, Cases on Administrative Law 242-67 (1951).

${ }^{19} 6$ Moore, Federal Practice $\$ 60.01(8)$ (2d ed., 1948).

${ }^{20}$ Fed. Rules Civ. Proc. 60(b): "On motion and upon such terms as are just, the court may relieve a party or his legal representative from a final judgment, order, or proceeding 
party which will persist if the injunction is continued and the hardships which dissolution or modification entails for the party who is protected by the injunction.

The major hardship for the enjoined party is an economic one. He is restricted in taking new steps. If an injunction is broad in scope or vague in phrasing a very large number of activities may be closed off to the enjoined party. If he did not operate under the injunction he would not be subject to contempt sanctions for incorrectly predicting what conduct is illegal. He would be subject only to those sanctions which the law would impose on his competitors. Moreover, if a governmental agency regulates the area of conduct, any unpredictability in the agency's actions will aggravate the hardship of the enjoined party. Finally, the enjoined party may be subject to the burden of being punished in a contempt proceeding where he does not have the procedural protections provided in a trial for violating the law. ${ }^{21}$

If the enjoined party is truly willing to abide by the law, the party protected by the injunction should not suffer any hardships if the decree is modified or dissolved. Safeguards should, though, be established to ensure that the enjoined party does have the requisite attitude. The party protected by the decree should not be put to the expense of petitioning for a second decree if the first is dissolved on inadequate grounds. Nor should he have to defend frequent actions for dissolution. ${ }^{22}$ It would seem wise to demand that attitude be proved by objective facts. The only method successfully used to date is proof of compliance with the decree over an extended period of time. ${ }^{23}$ One court has implied that a major change in the decision-making personnel

for the following reasons:... (5) the judgment has been satisfied, released, or discharged, or a prior judgment upon which it is based has been reversed or otherwise vacated, or it is no longer equitable that the judgment should have prospective application; or (6) any other reason justifying relief from the operation of a judgment."

21 For information on the subject of contempt penalties and procedures, see Moskovitz, Contempt of Injunctions, Civil and Criminal, 43 Col. L. Rev. 780 (1943); Affording Defendant Opportunity to Exculpate Himself, 22 Wash. L. Rev. 150 (1947). When imposing penalties for contempt the courts consider the good faith of the defendant a relevant factor. See NLRB v. Athens Mfg. Co., 163 F.2d 255 (C.A.5th, 1947); McComb v. Norris, 16 CCH Lab.Cas. I65198 (E.D.S.C., 1949). However, sometimes the contempt penalty may be set by a statute. For example, violations of the anti-trust laws are punishable by a fine of $\$ 50,000$. 69 Stat. 282 (1955), 15 U.S.C.A. \$1 (Supp., 1957). If a party is subject to a final cease and desist order of the FTC, he may be fined $\$ 5,000$ for each violation; each separate day of non-compliance constitutes a separate violation. 38 Stat. 719 (1914), as amended, 15 U.S.C.A. \$45(1) (1951).

2 On this ground the court in People v. Durkin, 191 Misc. 342, 77 N.Y.S.2d 442 (S.Ct., 1948), refused to allow dissolution of a decree enjoining a party from trading in stocks. He had shown that he had been leading an exemplary life since he was enjoined.

ss In Tobin v. Little Rock Packing Co., 202 F.2d 234 (C.A.8th, 1953), and Tobin v. Alma Mills, 192 F.2d 133 (C.A.4th, 1951), a ten year period was considered sufficient. In McComb v. Lexington Lumber Co., 15 CCH Lab.Cas. I64885 (E.D.S.C., 1948), dissolution was allowed after six years of compliance. In the Harnischfeger case, 142 F.Supp. 202 (E.D. Wis., 1956), the defendant had complied for twelve years when dissolution was sought and refused. 
of an enjoined company would be relevant in proving a change of attitude. ${ }^{24}$ A requirement that such objective facts be shown will safeguard the party protected by the decree.

The public has an interest which reinforces that of the party who obtained the decree; for, the threat of an injunction serves as a deterrent. The public interest in maintaining the force of this deterrence should be considered in any dissolution proceeding.

A reasonable compromise of the interests of the enjoined party, the public and the party who obtained the injunction might be achieved by the issuance of decrees labelled "indefinite" (instead of "permanent") with a provision that dissolution could not be requested prior to a specified date on the ground of a change in attitude. ${ }^{25}$ It would then be realistic to say that the question of the duration of the decree had been adjudicated and the possibility of a change in the willingness of the enjoined party to comply had been fully considered. If this suggested compromise were adopted the decree might still outlast its need but it would do so only for a very limited period. The deterrent value of injunctions could be protected by adjusting the length of the period during which dissolution could not be obtained on the ground of a change in attitude.

The issuing court should take into account such factors as good faith in attempting to comply with the law, willingness to conform to suggestions made by government agencies, the nature of the illegal conduct and the scope of the decree. In proceedings for modification or dissolution the court should consider not only these factors but also the conduct of the enjoined party since the injunction was issued, adoption of procedures making future compliance likely and changes in management. ${ }^{26}$

24 Tobin v. Alma Mills, 192 F.2d 133 (C.A.4th, 1951). In the Harnischfeger case, the district court specifically found that there had not been substantial changes in management. It avoided stating whether such changes would have justified dissolution. Since the court almost suggested that the defendant appeal, it was probably trying to eliminate the necessity of having the case remanded for findings of new facts in case the appellate court should decide that a showing that future violations were not to be expected was a ground for granting dissolution.

${ }^{25}$ This was done in Tobin v. Neely, $22 \mathrm{CCH}$ Lab.Cas. 167285 (N.D. Ga., 1952). The period allowed was one year; when the year expired the enjoined party was granted dissolution even though technical violations had been committed during the year. In Tobin v. Cherry River Boom and Lumber Co., 102 F.Supp. 763 (S.D. W.Va., 1952), the court issued an injunction against violations of the FLSA but provided that the defendant could request dissolution when he fully complied with the Act.

${ }^{20}$ As indicated in the introduction, the analysis given applies to court-enforced cease and desist orders of administrative agencies as well as to injunctions. The same policy reasons apply to both. No cases have been found in which a party sought to have an order modified or dissolved on the sole ground of a change in attitude; but it is clear that, like injunctions, enforcement orders can be modified or dissolved on the basis of changes in law or factual conditions. American Chain and Cable Co. v. FTC, 142 F.2d 909 (C.A.4th, 1944); Century Metalcraft Corp. v. FTC, 112 F.2d 443 (C.A.7th, 1940). The general rule seems to be that if the agency has been given power to modify its orders even after enforcement by the court, 